\title{
Political Perspective on Technology Alliances - the Cases of Microsoft and Google
}

\section{Krzysztof Klincewicz ${ }^{*}$}

\begin{abstract}
The article presents technological alliances as political activities, helping establish coalitions, co-opt supporters and eliminate rivals. Using the example of Microsoft's and Google's partner ecosystems, it discusses specific partnership techniques and their relevance for technology companies. The article offers a rich picture of developments of Microsoft Windows and Google Android platforms, combined with the steps taken by both companies to ensure support from partner firms. The effectiveness of financial, marketing and technological incentives as well as of deterrents depends on expected outcomes (such as: decreasing transaction costs, creating lock-ins, stimulating innovativeness or restricting development of competitive products) and technology life cycle stages. The article helps shape partnership strategies and optimize investments, needed to motivate and control partners.

Keywords: technological alliances, partners management, political perspective, Microsoft, Google
\end{abstract}

\section{Introduction}

Traditional approaches to alliances emphasize their cooperative aspects: combination of resources, leading to innovation and efficiency improvements. However, networks of firms are formed in political processes, balancing interests of various parties, and inter-organizational relations are often dominated by power struggles. The political perspective interprets organizations as entities with members pursuing their own, potentially conflicting interests, and with a limited number of actors coordinating scarce resources, thus establishing asymmetries in power (Astley \& Zajac, 1991; Elg \& Johansson, 1997; McLoughlin et al., 2001). In alliances, dominant firms defend and exploit their positions, while smaller partners attempt to reduce their dependencies.

The dynamic view of alliances which evolve over time focuses on joint problem solving and the gradual emergence of trust among partners (Ring \& Van de Ven, 1994; Das \& Teng, 2002). At different stages of the partnership process, formal elements such as bargaining, contract fulfillment and role interactions are complemented

* Krzysztof Klincewicz, Prof. UW Dr Hab., Faculty of Management, University of Warsaw, kklincewicz@mail.wz.uw.edu.pl. 
by informal sense making, psychological contract and interpersonal relations, thus creating opportunities to use social influence mechanisms. Firms use multiple direct mechanisms, influencing other players and making them follow a firm's desired actions (Elg \& Johansson, 1997, p. 364; Avakian, 1999):

- inducement - involving motivational investments, rewarding loyal partners;

- coercion - worsening of a party's situation unless it selects the suggested alternative, e.g. by restricting access to specific resources, or threatening to compete;

- obligation - binding the opponent to make him follow an intended course of action;

- persuasion - presenting rational or emotional appeals.

Firms controlling key technologies can maintain their dominant positions not only because of superior technologies and compelling strategic visions, but also thanks to the incorporation of political actions into their business models (Avakian, 1999, pp. 43-45). Power does not need to be linked to resources possessed by an organization - it can result from specific relations or social structures (Astley \& Zajac, 1991, p. 403; McLoughlin et al., 2001, p. 281). Political process consists of both observable moves (surface politics), as well as subtle activities, not directly involving exchanges of resources, e.g. by preventing issues from being discussed and decisions from being made (deep structure politics) (Elg \& Johansson, 1997, pp. 365-366).

The article will apply the political perspective to explain how a technology firm can use a broad portfolio of political "tools" to manage its partners. The political power of a company helps establish and successfully defend a technological standard (Anderson \& Tushman, 1990). By managing technological platforms (Cusumano \& Gawer, 2002) and ecosystems of partners (lansiti \& Levien, 2004), companies may promote their standards among complementors and customers. The prevalent perspective on alliances suggests that in an alliance, a partner contributing more resources has more chances to control the other party - but the following discussion will demonstrate that intelligent use of political tactics can reduce the need for tangible contributions.

Political sociology offers a useful analogy to the dynamics of high-tech industry: the Medici family exercised power in the renaissance Florence through networks or relations and interlocking interests without holding any official government positions, and the style of exercising power can be compared to the game of chess, where successful strategies involve locking-in other players, restricting their options and making them pursue strategies convenient for the winner. The phenomenon is described as blockmodel, with multiple ties restricting the choices of other players, including marriages, business partnerships, real estate ownership, personal loans and other obligations (Padgett \& Ansell, 1993). This heritage of political sociology will help understand the phenomenon of strategic interlocks by high-tech companies, using incentives and deterrents to induce and maintain partner loyalty. 


\section{Research problem}

The article overviews political techniques, which can be used by companies intending to establish and maintain technological dominance. The research is rooted in a complex qualitative analysis of analyses Microsoft's activities in multiple markets and through various groups of partners, with particular focus on the establishment of Microsoft Windows platform. It will further present corresponding actions taken by Google, following the footsteps of Microsoft in an attempt to promote its new operating system Android.

Microsoft is one of the largest high-tech companies, leading in multiple ecosystems - it partnered in 2007 with more than half a million companies, employing $42 \%$ of the global IT workforce (IDC, 2007). Popular literature presents the company as an unscrupulous player, and the image was reinforced by numerous legal disputes and widely criticized technological decisions. On the other hand, Microsoft managed to successfully diversify from its original product - operating system - by entering various emerging markets such as business applications, telecommunications software, multimedia players and computer games. This richness of experiences helped Microsoft develop a unique combination of partner management techniques, so far unmatched by industry rivals. Microsoft was probably the first software company seriously appreciating the role of complementors. Its partnership and certification programs were imitated by other companies, but the actual partner management framework consists of various elements overlooked by imitators. The following sections will outline the techniques applied by Microsoft, differentiating between incentives and deterrents, jointly used to motivate partners and to restrict their potential opportunism. Subsequently, the framework will be applied to present relevant actions taken by Google.

\section{Research methods}

Alliances should not be regarded as discrete events but rather processes and for strategy makers, alliance dynamics is more important than initial agreements. As the article discusses a complex and yet unexplored phenomenon, it adopts a case study approach based on qualitative data analysis. The Microsoft analysis was based on over 1,600 documentary sources, including IT press articles, industry analyst reports, interviews, corporate communication and documents of courts and regulatory bodies. They covered years 1994-2004 - a period of Microsoft's domination in personal and enterprise computing. The documents were coded and analyzed in qualitative data analysis software NVivo, which supported the subsequent theory modeling and testing in line with the methodological recommendations of the grounded theory approach. The subsequent analysis of Google was also based on secondary data, covering a more recent period of 2007-2011. The comparison of political actions taken by the two companies in different time periods supports data triangulation and strengthens the potential for generalization of research conclusions. 


\section{Research findings - Microsoft's use of political techniques}

The analysis demonstrated repetitive use of specific partnership techniques - they were applied by Microsoft to various groups of partners and technologies. The portfolio of techniques is summarized in Figure 1 and its detailed discussion is presented in the following sections.

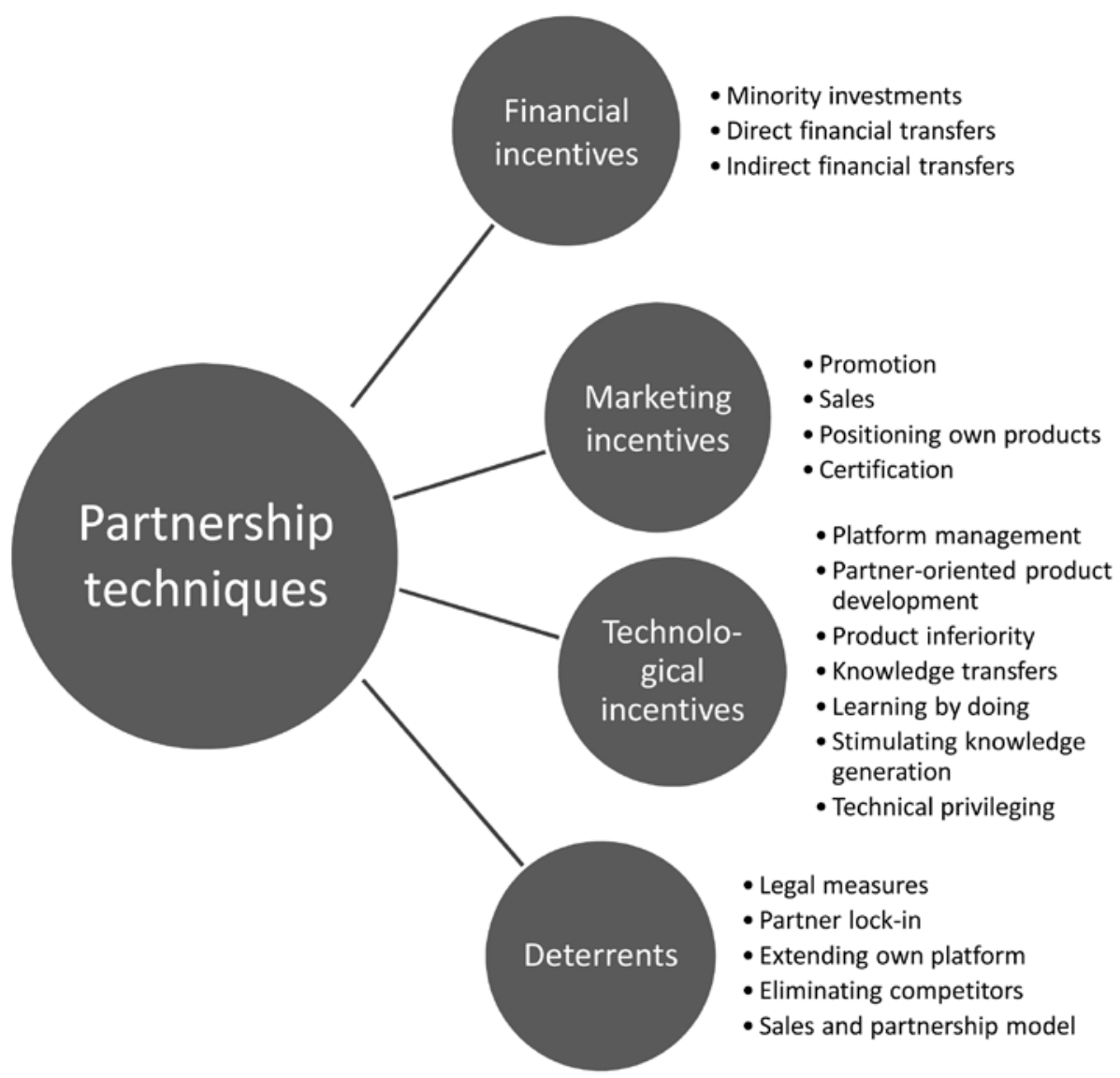

Figure 1. Partnership techniques used by Microsoft

\section{Financial incentives}

\section{Minority investments}

Academic literature discusses the trade-off between acquisitions and strategic alliances (Roberts \& Liu, 2001; Dyer et al., 2004; Kale \& Puranam, 2004), but for Microsoft, financial investments and alliances seemed to be independent phenomena. Equity investment helps implement product strategies by tying partners and inducing reciprocity, and possible motives include: 
- return on investment,

- payola,

- control over partners strategies,

- access to resources,

- signaling function.

Minority shareholding differs from an acquisition - the investment becomes a partnership technique, focused on generating added value from the ecosystem. Investments in technology start-ups are particularly risky - instead of venture capitalist logic, Microsoft was investing in partner companies to stimulate technology diffusion - firms were paid to develop products complementing Microsoft's technology platforms. This approach seems to be particularly effective for competencedestroying innovations, usually opposed by affected companies (Anderson \&Tushman, 1990, p. 612), as cash inducement helps align their strategies. First providers of complementary products must receive financial incentives to solve the "chicken-andegg" problem: if there is no installed user base, companies are not willing to invest in the development of compatible products, but users would not buy solutions without available complementary goods (Hill, 1997).

The investment can also block and „convert” a hostile firm - for example, Microsoft co-opted Infolmage and Interliant, important partners of its competitor Lotus IBM, by offering them financial benefits and technical opportunities (Deckmyn, $1999,2000)$. According to an analyst, "whereas once a company may have had its own agenda and been marching towards its own goals, an injection of Microsoft money meant that the company was turned around and had begun marching in Microsoft's direction" (Avakian, 1997, p. 47). In order to penetrate the emerging software markets for telecommunications, television and Internet providers, Microsoft in 1999-2001 placed investments in 29 client companies in value of over 9 billion dollars (Klincewicz, 2005, p. 115). Welfare economics introduced the term payola to describe situations, when a party is "paid to play" - support or promote specific products. The term was originally applied to radio stations, receiving payments from record companies for airing songs (Coase, 1979), but relates to other settings, when a party is "bribed" to support specific products. Among high-tech companies, struggling to establish own standards, payola plays important strategic role, helping buy users or supporters.

Microsoft used financial investments to settle patent and trade secret disputes. It invested in Stac Electronics, putting an end to controversies concerning use of its compression technology in Microsoft DOS (Johnston, 1994). Later investments in competitors such as Wang Laboratories, Apple Computers and Inprise (Borland) were combined with dispute-settling technology licensing agreements (Ouellette \& Weinberg, 1995).

Microsoft's investments alone did not guarantee the loyalty of partners - most evident examples of such disappointments are: Internet content provider Individual, partnering with Microsoft's rival Netscape, and multimedia streaming specialist Real Networks, pursuing its own competitive strategy (Evers \& McMillan, 2003). 
Access to unique resources could be a motive for minority investments, but effective control over technologies is possible only through majority shareholding or complete acquisitions, and non-equity based alliances might offer better synergies (Dyer et al., 2004, p. 111-114). When Microsoft was preparing the launch of video game console Xbox, it acquired or invested in multiple game developer firms, and later supplemented the group by of one of the largest specialists, Rare (Becker, 2002). The investments seemed to be the only plausible way to guarantee the supply of a satisfactory number of games in short time - a month after the Xbox release in 2001, 38 games were available, most of them developed specifically for the new platform (Weinstein, 2001).

Minority investments became a formalized ritual, not only offering the partners money, but more importantly, endorsing them as trusted complementors, as association with Microsoft could be a strong selling point. A demise of trust in mutual relations could in turn lead to de-investment as in the case of selling off shares of Real Networks, which dared to testify in court against Microsoft (Nash, 1998). The signaling role of marginal investments cannot be overestimated - for example, by providing financial support to former competitors, Microsoft was demonstrating its dominant power and announcing radical changes to the industry, sending a message to customers, and showing which company enjoys financial health bright future visions.

\section{Direct financial transfers}

Over the years, Microsoft perfected its portfolio of non-equity based financial incentives through direct and indirect transfers. They effectively replaced shareholding and helped provide funds for partners without the need to report it to shareholders. The available forms included joint development projects (with shared risk and resource input), subcontracted development work (one-directional payment, offering revenue opportunities to the partner) or ordering partner's services and products for internal purposes.

Joint ventures among key players in the converging computing, communications and media industries were frequent in the 1990s, even though their effectiveness is sometimes questionable. For example, due to its efforts to enter the emerging mobile data services segment, Microsoft established in 1998-2000 joint-ventures with the US telecommunications technology vendor Qualcomm, Japanese operator NTT DoCoMo and Swedish telecom giant Ericsson. None of them bore tangible fruits, all were later dissolved or internalized by partners, and Microsoft's contributions turned out to be worthless in the end. However, a more careful investigation shows that the ventures played an important blocking role. NTT DoCoMo did not select preferred operating system for cellular phones until 2003, leaving room for Microsoft's technologies. Ericsson committed to use Microsoft Mobile Explorer as phone web browser. Qualcomm decided to halt developments of Eudora mail server, competitor of Microsoft Exchange. In 2000, Microsoft formed a joint-venture Avanade with Andersen Consulting, employing thousands of consultants dedicated solely to Microsoft-based solutions, instrumental in positioning Windows as the platform for enterprise-wide applications (Dash, 2000). 
Subcontracted development projects are traditionally used to outsource non-core tasks, either requiring specific skills (e.g. development and maintenance of spell checker module, not related to other product technologies, while requiring a sound knowledge of linguistics), or time-consuming yet not sophisticated (e.g. software testing based on predefined procedures). Microsoft case revealed the popularity of another type of subcontracting, concerning complementary solutions, where Microsoft paid a thirdparty for development, in line with the model of payola. The practice was initiated by "buying" support for Windows NT - contracting various firms (including Tandem Computers, Digital Equipment Corporation and Banyan Systems) to work on integration between Windows and their own platforms, so that they could also benefit from selling these connectors and migration services. The companies were probably not sufficiently motivated to work on adequate technologies, as the costly development would simultaneously decrease installed bases of their own platforms - payments from Microsoft helped overcome the fears and spelled a prolonged death sentence to the other platforms. The same approach supported diffusion of other technologies Microsoft contracted in 1999 Transvirtual Technologies (Sliwa, 1999) and ActiveState Tool Corporation (Shankland, 1999) to develop Microsoft-compliant software for rival platforms. The company was from time to time using the development contracts also for other reasons: to help financially troubled companies, which it partly owned (e.g. Internet providers UUNet Technologies and XO Communications), or to fight political battles (SCO Group sued Linux community members for copyright infringement and Microsoft infused SCO with cash through a sizeable licensing agreement).

An innovative aspect of Microsoft's strategy was a close integration between procurement processes and the partnership program. Every large company needs to rely on third parties for IT infrastructure and support services, but Microsoft was selecting solutions not only technically superior, but also "politically correct". Purchasing decisions functioned as both endorsements for partners, as well as implicit pressure mechanisms, and historical analysis of Microsoft's relations with partners proves a surprising co-occurrence of orders for internal use and certain commitments by suppliers. Evidence made public in Microsoft-related litigations and lawsuits indicated the subtle but categorical tone in negotiations with hardware makers or other partners - incentives offered were accompanied by implicitly expected reciprocity. Large service contracts to support Microsoft's IT infrastructure were key motivators for Digital, Compaq and HP since 1994, and every renewal of the contract was followed by new commitments from the service provider. Microsoft's decision to implement SAP's financial software for internal purposes made SAP support relevant Microsoft technologies (Cafasso, 1994). The purchase of Computer Associates InocuLAN antivirus software coincided with an alignment of the CA's strategy around Windows platform (Golde, 1997). A contract for the Internet provision for Microsoft's portal MSN, awarded to $\mathrm{MCl}$, was synchronized with MCl's migration to Microsoft platforms, purchase of licenses and commitment to promote the standards to telecoms customers (Wong, 1997). 
The multiplicity of direct financial transfers in use suggests that Microsoft had a systemic approach to partners, not focusing on single transactions but rather on a broad network of interdependencies. Payments inefficient from the perspective of financial management were crucial in gaining support for emerging technologies, but convincing competitors to become your complementors is difficult and costly.

Paying other companies for working with Windows was not sufficient. The companies had their distinctive competencies and products, so the "partnership package" had to include strategic visions and migration paths for existing technologies, helping convert the companies into reliable partners, and convincing them that they could play equally important and profitable roles in the new market. The strategy was unique, as usually vendors of disruptive technologies focus on surpassing and eliminating incumbents (Christensen, 2000) - while Microsoft invited incumbents to join the disruptor's team, without a need to jettison what was precious to them.

\section{Indirect financial transfers}

Indirect financial transfers include investments through third-parties or decreasing partners' costs at the company's expense. The dedication of resources through an assignment of employees, adjustment of administrative procedures or purchase of dedicated equipment can be interpreted as investment in partners (Rokkan et al., 2003).

Microsoft was able to link capital seekers with appropriate funding sources, including venture capital firms or trusted partners such as Compaq or Intel. The mechanism was based on informal personal relations among Microsoft's directors and investor representatives - for example, Microsoft helped SCO Group receive investment from a venture fund BayCapital Star, by convincingly presenting SCO's prospects in relation to Microsoft's strategy (McMillan \& Evers, 2004). In order to stimulate the development of complementary solutions for Microsoft .Net platform, the company established Investor Connection program, working with venture funds to offer their customers infrastructure, access to knowledge and technical support (Luening, 2001). Such links could increase the credibility of technology start-ups, increasing their valuation and the availability of funds. Research confirms social embeddedness of transactions between institutional capital suppliers and their clients (Uzzi, 1999), and close ties with significant third-parties function as important endorsements (Gulati and Higgins, 2003).

Techniques decreasing partner's transaction costs might be even more attractive for partners. They include: pricing the access to technology (licenses or training), providing reference product designs and supporting marketing activities. Microsoft was providing selected trusted partners with royalty-free source code, attractively priced developer tools and subsidized training - the deviations from standard pricelists were adopted at the company's discretion, promoting businesses of preferred partners. Attractiveness of these offers was changing over time: the first large system 
integration partner Digital was offered free training for 1,500 engineers (Goldberg \& Bozman, 1995), while next service partners were granted less convenient commercial terms of the knowledge transfer. Correspondingly, changes to the official pricing and licensing policies were used to influence partners' strategies. The 1997 release of Microsoft Money, personal finance program, turned banks - so far customers - into partners, selling the software to own clients (MacDonald, 1997). In 2001 Microsoft showed support for the emerging Application Service Providers market by modifying its licensing model so that ASPs did not have to pay upfront for software rentals (Vijayan, 2001). The power of pricing arguments is best evidenced by the case of IBM: while negotiating a licensing deal to install Windows 95 on IBM PCs, Microsoft demanded IBM to delay the release of IBM's Lotus Smart Suite, competing with Microsoft Office, and IBM's refusal resulted in increased royalties the company had to pay for Windows (Wasserman, 1998).

Attractive pricing of technologies helps penetrate the market by discouraging other companies from developing comparable, competing functionality (Avakian, 1999, p. 45). This approach helped Microsoft establish its position among PC makers with DOS in the 1980s - hardware firms enjoyed the overall cost reduction and abandoned own investments in the operating system area, becoming locked-in by the technology. Penetration pricing of emerging technologies can be justified by learning effects and economies of scale, leading to subsequent dramatic decrease of unit costs, which compensate for the initial losses (Hill, 1997, p. 16).

The tradition of providing product reference designs is rooted in the software business, where tools, pre-defined templates and code samples were critical in gaining a wide-spread acceptance among the developer community. Microsoft adopted a corresponding approach to the hardware market. In the 1990s, it worked closely with component and device makers to reduce prices of Windows hardware, acknowledging the importance of hardware costs for software diffusion. Later it started contracting third-parties to design prototype devices, offered jointly with Microsoft software to hardware partners. Owing to the arrangement, hardware makers no longer need to conduct own R\&D in the concerned areas, using reference designs provided by Microsoft and dedicated contract manufacturers. The provision of reference designs helps boost adoption of new technologies both in software and hardware markets - but if applied creatively, it can also outstrip partners of their competencies and successfully lock-in by making dependent on technological standards.

\section{Marketing incentives}

\section{Promotion}

The most common partner incentive used by high-tech companies is joint promotion, done either by transferring funds to partners, or running campaigns with them. Owing to the scale of operations, Microsoft was able to run global campaigns, re-using designs and know-how. The preparation of marketing templates, scripts and manuals 
is also a form of investment in the partner community, reducing the necessary cost for partners interested in running a campaign. Microsoft offers the incentives to committed, certified partners, who have demonstrated the importance of the link by investing in establishing skills and designing own products in relevant ways (Microsoft's partnership program formalizes the rules, indicating conditions entitling to specific types of marketing and business support). Joint promotion is additionally attractive for partners, as it extends the appeal of Microsoft's brand to their certified products - for example, a marketing campaign "Plays for Sure", launched in 2004 by Microsoft, promoted partner multimedia devices compliant with Microsoft's standard (Borland, 1994).

\section{Sales}

Microsoft was reinforcing results of joint promotions by corresponding sales activities. The company established special sales channels for partners. Windows 95 with Internet Explorer offered a unique way of contracting Internet Service Provider - Microsoft hosted "Internet Referrals Server" with a list of authorized ISPs, and customers clicking on the Internet icon were able to select one to setup the connection (Pelline, 1996). This is one of many examples of product bundling, a practice typical for Microsoft, and frequently criticized by anti-trust authorities. However, the legal criticism concerned the bundling of own products to undermine sales opportunities of competitors, while here the innovative platform design helped Microsoft offer sales-related incentives to selected partners, benefiting from Windows user base.

Microsoft was also bundling complementary goods, improving own platform and offering sales opportunities to partners. Examples include: Macromedia Shockwave (animation viewer bundled with Internet Explorer, supplemented by commercial tools for creating the media files, sold by Macromedia) (Ricciuti, 1996), Symantec WinFax (offered with Outlook to send basic faxes, upgradeable to full version) (Luening, 1998) or Crystal Enterprise (reporting module for Microsoft CRM, with a paid upgrade for more specialist reports) (Cowley, 2002). Partners had twofold revenue opportunities: initial payment for the bundled component from Microsoft, and sales of related upgrades. Moreover, some cases involved symbolic bundling, when Microsoft embedded noncritical components from a partner with the sole purpose of promoting the partnership and rewarding the loyal company - for example, Windows 2000 included minor utility software from Computer Associates' Unicenter solution, and CA was able to position Unicenter as the recommended solution for this operating system (Heskett, 1998).

Microsoft was one of the first high-tech companies that made own sales representatives responsible for the sales of partner products - their targets involved of course also sales of relevant Microsoft licenses, pulled through by partner solutions. For example, an implementation of a specialist business solution requires Windows and SQL Server database licenses, and the deal may be equally profitable to Microsoft and partners, while the partner application is needed to sell the underlying platform. Microsoft's sales strategy is based on "go-to-market" initiatives, where account 
managers work with key customers in a vertical market, offering them complex business packages, consisting of Microsoft's and third-party products, accompanied by implementation services from a reliable partner. Instead of selling off-the-shelf software such as Windows or Office, Microsoft considers how these products can add value and address customers' problems. Customers of Microsoft platform form target markets for partners, using Microsoft-controlled communication channels and Microsoft benefits from the availability of new value-adding solutions for these customers.

\section{Positioning own products}

An important incentive, promoting the openness in partner relations, is the positioning of own products. Microsoft frequently positioned them as complementary or inferior to partner solutions. When releasing new products in domains previously controlled by partners, Microsoft was convincing the affected partners to cooperate and supplement the offering, even if the products were posing considerable threats to their businesses. For example, Microsoft entered document management market with SharePoint Portal Server - its first version was positioned as collaboration portal for teams and departments, gaining support from major document management vendors, and the second version was released as a scalable platform for managing documents, competing with the incumbent solutions, but partners remained loyal and supportive. Similarly, Microsoft's plan to enter CRM market was opposed by many partners - CRM specialists, perceiving it as a direct threat, but the company promoted the new product among small and medium-size organizations only. Microsoft is capable of successfully partnering with key players in specific product areas, while developing own competing solutions - the partners try in turn to benefit from the time left to them and penetrate the Microsoft customer base before becoming competitors.

Microsoft's approach resembles historical salami tactics. Hungarian communist Rákosi compared the ways of dealing away with opposition to slicing the salami - slowly cutting thin slices until the entire sausage is chopped without protests. The salami metaphor emphasizes hidden agendas and crafty character of the product marketing process: intentional positioning of own products as inferior to keep potential competitors confident, and later striking them by revealing the actual potential of a product.

\section{Certification}

Certification programs offer affiliation with the dominant player's brand. They assure customers about potential benefits of partner solutions, their compatibility with technology platforms and design, based on recent standards and best practices. Microsoft adopted two certification frameworks - for partner companies and for their products. Partner certification is linked to professional training and examination, and partners are required to employ a prescribed number of engineers specializing in Microsoft technologies. Product certification refers to solution architecture and features, and is awarded after independent technical tests. Customers working with 
a certified Microsoft partner can expect the company to possess adequate technical skills, while their decision to purchase products certified as compliant with certain platforms is based on implicit guarantees of product quality - certifications perform important signaling functions in complex markets as it differentiates suppliers. Microsoft introduced multiple partnership levels - although the partnership program rules are formalized, they are not audited by third parties, so it is at Microsoft's discretion to promote a specific partner to a higher status, thus offering yet another instrument of power. Similarly for certified products, Microsoft tends to select some of many comparable partner solutions to include them in "go-to-market" initiatives, deliberately promoting the most loyal partners, who do not offer solutions for competitive operating system or database platforms.

Apart from the benefits, partnership programs are troublesome to partners: they require substantial investments in training and certification, especially as Microsoft regularly overhauls the curricula, requiring companies to upgrade their knowledge once new technologies are released, while product certification is costly: testing is a paid service, and product development must comply with Microsoft standards and development methods.

\section{Technological incentives}

\section{Platform management}

Microsoft offers a seminal example of platform management (Cusumano \& Gawer, 2002): offering software layer, on top of which third-parties can build own solutions. Partner products become technically dependent on the platform, and could not be implemented in a stand-alone mode. Partners are aware of the dependency, carefully weighting arguments before they decide to support a specific technology, and Microsoft has to guarantee the continuous development and migration paths between technology versions. For example, when managing the transition from 16- to 32-bit Windows, the firm had to minimize the technology's impact on partners, investing to make it backwards-compatible. Third-party projects require the platform openness, with programming interfaces and development tools - Microsoft was offering them for Windows, and later started designing other products in similar ways. The platform strategy involves substantial investments in technology development - power in partner relations is inextricably linked to responsibility.

\section{Partner-oriented product development}

In order to gain support for its platform, Microsoft had to design it in ways compliant with partner products. This required a good understanding of partners' needs, specificity of their solutions and future directions of technology development. Every release of Windows included support for specific processors, hardware (with drivers for peripheral devices, updated and tested by Microsoft) and software. Software integration was also helpful in penetrating user bases of competitors - as in the cases 
of document import-export filters for text editor WordPerfect in Microsoft Word, and connectors to products from Oracle, Sun, Lotus or Novell.

Partner-oriented development is also evidenced by involvement in standard setting initiatives, extending beyond Microsoft's core competences. It pursued hardware-related projects with partners to establish new standards and support them in Windows - examples include: Plug-and-Play interface (automatic recognition and configuration of peripherals), computer standardization projects with Intel, Compaq and ARM, focused on reducing the manufacturing cost and optimizing performance, early support for emerging standards such as USB, FireWire and WiFi. Microsoft implemented also software interfaces, enabling interoperability of multiple software systems in Windows environment. The complementary nature of high-tech products made in many cases the partner-oriented development a necessity - when Microsoft wanted to enter the business-to-business market with transaction processing platform BizTalk, it offered connectors to four major online exchanges from Ariba, CommerceOne, Clarus and VerticalNet, investing in development of connectors but gaining access to potential customers (Sliwa, 2000).

\section{Product inferiority}

New products may initially not be appealing to mainstream customers, but by gradually improving performance they can substitute previous alternatives (Christensen, 2000). Their inferiority results from the nature of technology development cycles, where disruptive technologies are catching up with incumbents. Microsoft offers however examples of a more sophisticated approach, based on intentional inferiority. The company was liaising with partners, keeping low profile of certain products, for which partner-made counterparts existed. By deliberately halting the development of own components, it offered "grace periods" for partner applications. Microsoft DOS included antivirus functionality, but in Windows, the company decided to leave this domain to partners (Johnston, 1995). When releasing Windows XP in 2001, Microsoft wanted to offer sales opportunities to existing media software partners, especially as the system bundled various features previously contributing to their revenues - the company decided not to offer DVD playback and MP3 ripping functionality, promoting add-ins from CyberLink, InterVideo and Ravisent (Wilcox, 2001a). Online shop MSN Music did not exploit all technically available opportunities - Microsoft intentionally left time-limited music rentals and monthly subscriptions to partners and restricted own sales to pay-per-song downloads. Intentional inferiority could be dangerous for partners, lulling them into security, while the decision not to develop certain functionality could easily be changed: after some time, Microsoft released own antivirus software, started offering DVD and MP3 support in Windows and adopted new pricing models for Internet music. Nevertheless, the intentional inferiority offers at least temporary revenue opportunities for partners, becoming an important technical incentive in strategic alliances. 


\section{Knowledge transfer}

Training, technical documentation and dedicated support help transfer specialist knowledge to partners and enable them to build own solutions. These activities can be a revenue opportunity or a form of investment, and many firms are indecisive as to whether they should focus on cashing from partners, or establishing long-term advantage by investing to build the partner's competences and boost diffusion of own products. For mature companies, revenues driven by customer projects implemented jointly with partners seem more promising than earning money merely from partners, and partner training events are often delivered at cost or even below cost. Microsoft's experiences demonstrate the benefits of flexible pricing of knowledge transfer - the company was willing to cover all costs for first partners, needed to gain the critical mass for new technologies (for example, 1,500 of Digital employees were trained at Microsoft's expense (Goldberg \& Bozman, 1995)), and large partners were offered attractive commercial conditions in return for their commitments to product development, support and employee certification.

Knowledge transfer for partners can therefore be interpreted as resulting from interplay between four possible motives:

- financial motive - offering revenue for the company, either direct, or indirect (as partners are expected to sell more effectively);

- technological motive - supplementing technology platforms by complementary products and professional implementation services;

- commitment motive - inducing partner loyalty and reciprocity, when the company indirectly invests in a partner by covering costs, or the partner makes relation-specific investments in training and certification, later limiting opportunism, as investments generate sunk costs once the relationship is terminated (Wathne \& Heide, 2000);

- marketing motive - by signaling partner competencies to customers and growing support for own platform - for example, partnership with one of the largest system integrator EDS was critical to the successful introduction of Windows, as large customers were often disappointed by the quality of Microsoft technical support, and addition of 7,000 experienced service professionals from EDS was a move welcome by the market (Cole-Gomolski, 1999).

Discretional financing of activities helps influence the strategies of partners and should be managed as part of a comprehensive partnership program. Requiring partners to make own investments in training and certification facilitates in turn their self-selection into the relationships, as they have to prove willingness to bear the costs and efforts (Wathne \& Heide, 2000). Knowledge transfer activities include not only training, but also assignment of own technical specialists, who work with partners on specific sales or development projects, help design solutions, and evaluate technologies or marketing plans. In the case of Microsoft, distinctive corporate culture facilitates joint projects even when not every aspect is governed by non-disclosure agreements, enabling informal access to information and decision makers. 


\section{Learning by doing}

Learning by doing is an important technical incentive for partners, enabling them to experiment with technologies and build relevant competencies. Tacit knowledge, which is particularly important for technology projects, can only be acquired in action and cannot be substituted by even best formal training or documentation. For emerging technologies and new product platforms, Microsoft helped partners acquire necessary skills by offering learning opportunities through contracted projects, joint development and supply of specialist services for internal use, enabling them to subsequently approach customers and demonstrate own proficiency and references. These projects had thus three parallel functions:

- financial - being an incentive for partners;

- tangible - delivering specific technical outcomes, useful for Microsoft's operations or technology development;

- intangible - helping partners learn to better know the platform and be able to deliver solutions for customers.

Joint partner projects, focused on the establishment of new standards, were also intended to build a reliable complementor and service provider base for Microsoft technologies. An alliance with the networking giant Cisco Systems offered specialist contribution to Active Directory included in Windows, but also improved Cisco's understanding of the platform (DiDio, 1997). Multimedia format ASF was developed by Microsoft-led coalition of software and media companies such as Adobe Systems, Avid Technology, Digidesign, Pinnacle Systems, Softimage, Sonic Foundry and Truevision, which built their own compatible product lines (Busse, 1998).

\section{Stimulating knowledge generation}

Knowledge and skills in new technology-related areas do not need to be transferred directly by the platform owner - the company may become knowledge facilitator. Microsoft established partner community, in which partners were able to achieve additional synergies, contributing to the diffusion of technologies. These activities can be compared to a "bazaar", where other market participants meet and cooperate (Gulati, 1995), as personal interactions and inter-organizational dynamics play vital roles in creation and distribution of knowledge. Microsoft runs regular events for partners and individual developers, stimulating networking among business and technical people. The company uses Internet to support virtual communities through self-support online discussion groups, chat rooms and wikis on a website named Channel9 (Evers, 2004).

To further stimulate knowledge generation, Microsoft thinks about strategies for partners. It seems to apply the competency management perspective not only internally, but also to businesses of other firms, identifying their core competences and planning their evolution in parallel to the development of Microsoft's products. Trusted partners benefited from repeated ties, working with the software giant on many projects and thus improving own skills - for example, in hardware area, Microsoft 
partnered with the same companies on the development of respectively handheld and tablet computers, smartphones, Media Center PCs and portable media players. All devices shared common components, while each product category had also features, requiring new technical expertise - Microsoft's partners could thus re-use some knowledge, and supplement it by new elements. This approach helps reduce potential resistance of partners and shorten the technology adoption process by showing that the promoted innovations are competence-enhancing (Anderson and Tushman, 1990, p. 612). As the response of the community of practitioners is critical for the commercial success of new technologies, Microsoft took the initiative to facilitate communication and thus influence perceptions and technology decisions.

\section{Technical privileging}

Even though Microsoft technologies seemed open for interested parties, the control of proprietary technical standards enabled Microsoft to privilege or disadvantage individual partners. Exclusivity, traditionally used in other business sectors, does not seem a plausible contractual means in the high-tech industry, where knowledge spillovers are difficult to prevent, and restricting clauses questioned by antitrust authorities.

Instead, the company restricted access to specialist technological knowledge in more creative ways. Standard developer tools, documentation and code samples were often not sufficient for partners developing certain solutions. For example, toolkits for Unix-Windows applications porting, written by Microsoft partners in the 1990s, required access to the actual Windows source code. The case of Bristol Technologies shows the real bargaining power of Microsoft. After several years of successful cooperation, Bristol was denied access to the code (or rather required to sign a revised, unfavorable contract), and had to give up the product development (Sykes, 1998). Similarly, not all programming interfaces for Microsoft products were available to partners - some were public, some available to certified partners, and others used only internally by Microsoft and its most trusted partners (though European Commission obliged Microsoft to disclose the relevant technical documentation).

Microsoft's approach involves using seemingly open standards, which could attract as many interested parties as possible, but modifying them slightly to control the group of partners having access to some added-value features of the technology, guaranteeing loyalty by an implicit technological blackmail.

Partners involved in standard setting and development of specifications are privileged over other parties because of the early access to technologies and more profound knowledge than provided by official documentation. Microsoft was also embedding in its products components developed by certain partners, offering them opportunities to apply insider knowledge and develop solutions by using methods not available to other players. Wang Laboratories were working with Microsoft on the development of MAPI, an underlying messaging layer for Windows, and benefited from the work by promoting own workflow system to the indignation of other vendors 
(Ouellette, 1995). On the other hand, Microsoft's competitor in the portable devices market Palm was not able to strike an interoperability deal with the company - as a result, Palm-based appliances were not able to easily synchronize with Windows computers (Garretson, 2002).

\section{Deterrents}

\section{Legal measures}

Microsoft's licensing agreements, restricting scope of partners' activities, were frequently debated in courtrooms. The public criticism forced the company to amend its contract templates, dropping some controversial clauses, such as requirements to offer bundled products (e.g. Windows with Internet Explorer, or Internet Explorer with pre-defined Internet content in Active Channels). Microsoft initially barred partners from selling competitive products - hardware makers could not install other operating systems or browsers on PCs (Thibodeau, 1999; Niccolai \& Trott, 1997), and ISPs and content providers were prohibited from informing customers about the existence of alternatives to Internet Explorer (Goodin, 1998a, 1998b). Some licensing deals were constructed in ways making the distribution of competitive solutions unprofitable royalties paid by PC manufacturers for Windows were calculated based on the overall number of computers they manufacture, regardless of which operating system they were shipped with, thus discouraging alternative installations (Caldera, 1996). Partners were also prevented from developing products integrated with Microsoft's competitors - software developers working on applications for Windows 95 received non-disclosure agreements, restricting their involvement in specific competitive initiatives and prohibiting work on own development tools (Johnston et al., 1994).

Such techniques may undermine the intrinsic motivation of partners, exposing the focal company to legal and image problems. Interestingly, relaxing these sometimes outrageous requirements was interpreted by the market as a positive sign, and attracted new supporters for Microsoft technologies.

\section{Partner lock-in}

Lock-in conditions occur when a party cannot terminate the relationship without incurring losses or high switching costs (Farrell \& Shapiro, 1988). Companies try to take hostages from their partners in form of investments in relation-specific assets, and the creative use of lock-ins became a wide-spread practice in technology management. Semi-openness of technological standards creates an effective partner lock-in their integrated products cannot easily be ported to other platforms, competencies acquired over time are inextricably linked to the supported technology, while sales relations limit their commercial options.

Even the seemingly open hardware drivers architecture in Windows, designed by Microsoft to support as many compatible devices as possible, offered a way to restrict partner strategies: Kodak accused Microsoft of maintaining control over the 
user experiences for digital cameras by streamlining all photo handling processes with bundled software, thus not leaving space for third-party solutions (Wilcox, 2001b). When Microsoft introduced a universal messaging interface MAPI in Windows, developers of competing e-mail software Lotus and Novell abandoned their standardization efforts and supported MAPI only to later discover that Microsoft concealed some elements of the interface, giving Microsoft Exchange a head start on competing systems (Mohan, 1995). ISPs including AOL and Lycos, who licensed Internet Explorer 4.0 code and built custom browser versions for own customers, were later not able to benefit from new features as the architecture of version 5.0 changed (Krigel, 1999).

Probably the most inventive example of technology lock-in was Microsoft's settlement with InterTrust Technologies. InterTrust accused Microsoft of infringing its patent for multimedia rights protection. Microsoft agreed to license the patent, but its validity would be limited to standard implementations of the relevant Microsoft platform. Microsoft's partner - media player maker, online media shop, or media editing software vendor - intending to enrich the technology would have to negotiate separate licensing terms with InterTrust (Roberts, 2004). Because of the substantial costs, everybody preferred to stick to the standard version, thus not endangering Microsoft's dominance in the emerging market. Technology platform locks in partners, restricting their future technological choices and preventing entry in certain markets, while creative strategies allow companies to use other parties to deepen the lock-in, as in the case of litigation threats by an external patent owner.

\section{Extending own platform}

While intentional product inferiority and relevant positioning offered partners revenue opportunities, the opposite scenario could be used as an important deterrent. Microsoft was frequently capturing new niches by entering them with own solutions, bundled with established products and cheaper than previously available alternatives.

Pre-emptive product announcements helped eliminate potential competitors, who were abandoning their development plans once Microsoft announced the future availability of certain solutions (even if the announcements were only in early stages and concerned products that never materialized) (Avakian, 1999, p. 47). This mechanism can be interpreted as a counterpart of the inferior product positioning, used as a powerful deterrent to manage expectations of market participants (Farrell \& Saloner, 1986).

\section{Eliminating competitors}

The previously described payola does not only motivate partners, but also restricts competitors or reduces support for competitive standards. Microsoft tried not to completely eliminate competitors, trying rather to make them dependent on own standards and limit their user bases. The company acquired minority stakes in its competitors Apple, Inprise and Corel, helping them financially in return for strategic subordination. Linux supporters were incensed by Microsoft's acquisition of antivirus business unit of GeCAD Software - its RAV AntiVirus was the best 
antivirus solution for Linux platform, no longer available after the acquisition (Evers \& Roberts, 2003). Additionally, Microsoft was offering benefits to partners, willing to suspend development of competitive products - for example, HP agreed to give up its e-mail server OpenMail for Windows and support Microsoft Exchange in return for involvement in various joint initiatives and the preferred supplier status (Mohan, 1997). Microsoft was also trying to "convert" key partners of its competitors (as the previously described IBM partners Infolmage and Interliant), or restrict competitors through legal settlements. For example, the company agreed to pay a substantial settlement in patent lawsuits with Sun Microsystems, but Sun was expected to improve interoperability of its products with Microsoft platform (McMillan, 2004). There were cases, when Microsoft intentionally modified own products to disable the usage or deteriorate the performance of competitive applications - Real Networks player failed to run once a competitive Microsoft's product was installed (Johnston, 1998), and web browser by Opera could not display correctly pages of MSN, as the portal was generating different page views, depending on browser software identified (Hansen \& Festa, 2004).

\section{Sales and partnership model}

Another deterrent is Microsoft's sales and partnership model, including elements of the plural governance form (Baker, 1990): parallel work with multiple partners, who compete in specific technological domains and are thus motivated to innovate and differentiate their offerings. This approach limits reliance on individual partners, strengthens Microsoft's bargaining position and preserves the commercial character of relations. Multiple channels and partnership levels support in turn creative distribution of margins and link them to partner investments in marketing, training and technology development.

\section{Research findings - Google's use of political techniques}

Google's attempts to increase the user acceptance of Android, its operating system for mobile devices, resembles the previously presented Microsoft case. Google can be regarded as Microsoft's disciple, as its technological ecosystem resembles the comprehensive network of Microsoft partners. Android is a multi-purpose operating system, initially developed for mobile phones, but with its reach set of features, it is also being used in tablets, electronic devices such as GPS receivers, e-book readers, music and video players, television sets, and even personal computers. While still consider as less powerful and less sophisticated than Microsoft Windows, it has the potential to endanger the platform's market position, especially for end-user devices. It is important to recognize the similarities between Microsoft's and Google's approaches, as Google's emulation of past Microsoft's activities might yield similar strategic outcomes.

Android continues to rapidly evolve and it seems too early to present its comprehensive historical analysis as the previously described case of Microsoft. The 
complex analysis is not feasible yet due to the relevant newness of developments and limited data availability. Nevertheless, Google displays significant similarities to the partnership techniques adopted by Microsoft and described in this article. The company notably refrains from some controversial techniques, which created antitrust problems for Microsoft in the past, thus learning from its predecessor's experiences.

Google uses financial incentives on a limited basis, but the overall approach to using money as a means to make friends emulates Microsoft's implicit philosophy. Minority investments helped Google secure support for its system platform - an example is games developed by Zynga, initially offered for web-based Facebook platform only, but later released also in Android versions (Carlson, 2010). A variety of direct financial transfers, including joint development projects and subcontracted work helped Google attract and motivate the most promising third-parties.

Indirect financial transfers related to Android are more straightforward than in the Microsoft case. Android operating system is free, and its use for hardware products does not require royalty payments to Google. When compared with competitive mobile operating system platforms, Android is thus subsidized by Google. The company benefits from an advertising-oriented revenue model, and this is a major difference from Microsoft's license-based revenue structure. Making Android available free of charge was an important step in market development, gaining Google numerous supporters, including hardware, software, services and content providers. Among other indirect transfers, Google provided legal advice to Samsung and other Android device manufacturers in patent and copyright infringement cases brought to courts by Apple, Nokia and Microsoft. Moreover, there were speculations that Google covered the costs of professional services of law firm Quinn Emanuel, which was representing Google's partners in infringement lawsuits related to Android-based devices, as part of an indemnity agreement, offered by Google to its partners in order to encourage Android's adoption and limit the legal risks of supporters (Cheng and Sandoval, 2012). Another example of unusual indirect financial contributions was the transfer of two Google's patents to its partner HTC, in order to help the company fight its legal battle against Apple (Cheng, 2011b).

Marketing incentives are implemented on the scale similar to the past determination of Microsoft, helping partners find win-win opportunities within Windows ecosystem. Partners can benefit from promotion (campaigns run jointly with Google) and sales channels (through Google Play application market and Google-controlled hardware distribution channels). Google makes careful decisions about the positioning of own products in order to avoid direct conflicts with partners. For example, Google's own mobile phones branded as Google Nexus, manufactured by Google's Asian partners, have distinctive sets of functionalities, but the company makes sure that handsets sold by its partners are still attractive. A certification scheme is implemented to confirm compliance with Google-imposed standards. Apart from a formal acceptance track for new hardware products, inclusion of software applications in Google Play application market also requires validation by Google, confirming safety and conformance to system and design requirements. 
Among the possible technological incentives, Google clearly engages in platform management. Android is an operating system platform, offering opportunities for hardware manufacturers and software developers thanks to the available hardware specifications, as well as the existence of Google Play, an application distribution channel. Partner-oriented product development involves among others support for multiple hardware models and availability of drivers for standard peripheral devices. Releases of subsequent Android versions are prepared in ways facilitating their adoption by hardware manufacturers, including upgrade tracks and backwards compatibility. In some contexts, Google also uses the product inferiority technique. Even though relevant technologies are available or could easily be developed by Google, some functionality is lacking in specific applications, e.g. as of 2012, there is no offline support in Google Docs for Android, and no dedicated offline task application. Both areas present revenue opportunities for Google partners. Also, the company adopts a staged introduction of new functionalities in order to match the offering of major competing ecosystems, but at the same time prepare partners for the changes and offer them time to look for new differentiators and product concepts. There is a wide variety of knowledge transfer scenarios. Google partners can benefit from online learning opportunities, question and answer database, and developer documentation. When introducing Android, Google established close cooperation with key mobile phone manufacturers from Taiwan and South Korea, who in the past used to be important manufacturing partners of Microsoft. Learning by doing happens through the multiplicity of handset and tablet models manufactured by partners, enjoying regular technical help from Google and opportunities to experiment with hardware and software. Stimulation of knowledge generation occurs through the community of Android developers, at the same time Google engages in repeated ties with specific partners in new product areas, from mobile phones through tablets and other electronic devices, all of them using Android system. Technical privileging is effectively enacted even tough Android is seemingly open software. In fact, preferred partners get special treatment, with early developer previews, involvement in the preparation of system roadmaps and access to detailed technical documentation.

Deterrents are used by Google with extreme caution, as the company clearly does not want to experience the antitrust problems that Microsoft had in the past. Among legal measures, Google assembled a portfolio of patents, supplemented by the acquisition of Motorola Mobility, a major mobile phone manufacturer (Cheng, 2011a). It also adopts restrictive licensing agreements, requiring partners to adjust Android to their devices and submit the software for Google's approval.

Partner lock-ins are achieved thanks to the steep learning curve for Android. Entering the ecosystem requires substantial investment in knowledge acquisition, as development of software and configuration of hardware for Android differs from corresponding activities conducted for other platforms. Extending own platform happens as Google gradually adds new functionalities to the system, and thus enters new areas, previously handled by partners. Examples include: release of Chinese input 
interface for Android, improvements in standard system web browser, eliminating the need for alternative solutions, and development of Google Drive, substituting various applications, supporting cloud-based document storage. Software partners realize that Google would be capable of implementing most of software functionalities currently available from third-party applications, but for some reasons refrains from this. Similarly, Google releases Android hardware under its own brand, manufactured by selected contractors, but does not display ambitions to dominate the market with Google-branded devices, thus leaving space to other parties. Sales and partnership model is based on the previously described plural governance form, with Google's openness to new partnership, maintaining multiple partners in each area, stimulating the competition among them and introducing seemingly objective rankings in Google Play application market. Google does not officially use the technique of eliminating competitors, so there are no examples, which could be quoted here. However, once Google is targeted with lawsuits by competitors and undergoes scrutiny of regulatory bodies, relevant information might become available.

Google uses most of partnership techniques described in the article, and the strategy seems an emulation of Microsoft's approach, established in the 1990s. However, the analysis of Google Android ecosystem involves additional elements, which were not present in the case of Microsoft Windows. Android is open source software, which can be freely used by other organizations. The fact facilitated creation of Google competitors, directly using results of Google's work but establishing own ecosystems and undermining Google's revenue opportunities. Examples include modified Android software and related software distribution platforms from: Amazon (Kindle Fire), Barnes\&Noble (Nook), Xiaomi (MIUI), as well as non-commercial developer community, maintaining Android release called CyanogenMod. Google also needs to work closely with telecom providers, a very specific group of partners, requiring customizations of phone operating systems, making the Android ecosystem very complex, with multiple not fully compatible releases of the same version of Android, adjusted to requirements of specific telecom operators. The complexity generates additional costs and technical problems for Google, but offers additional motivation for Google's partners and increases their satisfaction.

Google is avidly following Microsoft's partnership model described in the present article. Interestingly, Microsoft departed from its customary approach in 2012, with the release of Windows 8 and start of direct sales of dedicated laptops and tablets, dubbed 'Microsoft Surface'. While Google tries to assemble as big an 'army' of Android partners and supporters as possible, Microsoft plans to loosen the long-term ties and become more selfsufficient. The move could be risky, as Windows strength used to lie in the broad support by third-parties. Microsoft seems to imitate the strategy of Apple - leader of another operating system platform, a company controlling key software, hardware and end user experience, thus dominating technology partners and not being vitally interested in their benefits or synergies within the ecosystem, but rather remaining focused on maximizing own revenues, often at the cost of partners. It is possible that Google Android ecosystem would replace the previous partnership structure, maintained by Microsoft for its Windows platform. 


\section{Conclusions}

The research outlined the multiplicity of available partnership techniques, but companies trying to learn from Microsoft's and Google's experiences should consider the effectiveness of these techniques in specific situations. Table 1 presents their varying relevance for the following scenarios: decreasing transaction costs (thus attracting new players to the ecosystem), stimulating relation-specific investments (in order to induce commitment), increasing innovativeness (focus on long-term health of the technological platform) and restricting new product development decisions (blocking potential rivals).

Table 1. Partner management techniques and their impact on strategies of partners

\begin{tabular}{|c|c|c|c|c|c|}
\hline & Partnership technique & $\begin{array}{l}\text { Decreasing } \\
\text { partner's } \\
\text { transaction cost? }\end{array}$ & $\begin{array}{l}\text { Stimulating } \\
\text { partner's } \\
\text { relation-specific } \\
\text { investments? }\end{array}$ & $\begin{array}{c}\text { Stimulating } \\
\text { partner's } \\
\text { innovativeness? }\end{array}$ & $\begin{array}{c}\text { Restricting } \\
\text { partner's } \\
\text { new product } \\
\text { development } \\
\text { decisions? }\end{array}$ \\
\hline \multirow{5}{*}{ 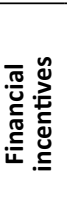 } & Minority investment & & $\mathrm{v}$ & & $\mathrm{V}$ \\
\hline & Direct transfers & v & v & v & v \\
\hline & Third-party investment & & $v$ & & v \\
\hline & Pricing technology & $\checkmark$ & v & v & $\sqrt{ }$ \\
\hline & Reference designs & $v$ & & & v \\
\hline \multirow{4}{*}{ 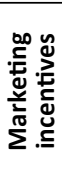 } & Promotion & $\sqrt{ }$ & $\sqrt{ }$ & & $\sqrt{ }$ \\
\hline & Sales & 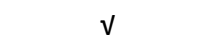 & & & v \\
\hline & Positioning own products & 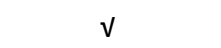 & & $\sqrt{ }$ & \\
\hline & Certification & & $\mathrm{v}$ & & v \\
\hline \multirow{7}{*}{ 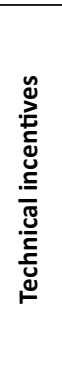 } & Platform management & $\sqrt{ }$ & & & $\sqrt{ }$ \\
\hline & $\begin{array}{l}\text { Partner-oriented } \\
\text { development }\end{array}$ & $v$ & & & \\
\hline & Product inferiority & 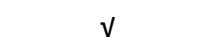 & & $\sqrt{ }$ & \\
\hline & Knowledge transfer & 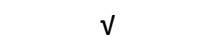 & v & 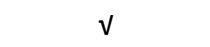 & v \\
\hline & Learning by doing & $v$ & v & v & $v$ \\
\hline & $\begin{array}{l}\text { Stimulating knowledge } \\
\text { generation }\end{array}$ & $v$ & & $\checkmark$ & \\
\hline & Technical privileging & $\sqrt{ }$ & & & \\
\hline \multirow{5}{*}{ 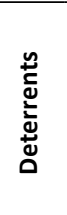 } & Legal measures & & 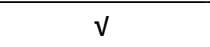 & & $\sqrt{ }$ \\
\hline & Partner lock-in & & v & & v \\
\hline & Extending platform & & & v & \\
\hline & Eliminating competitors & & 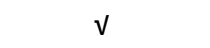 & & $\sqrt{ }$ \\
\hline & Sales and partnership model & & v & $v$ & \\
\hline
\end{tabular}

Partner management techniques help establish coalitions to support new technological platforms. Availability of complementary products is critical, so "buying" partners and treating them with respect is advisable. Partners are also needed to add credibility to the core technology and to shorten time-to-market (Roberts \& Liu, 2001, p. 27) - Microsoft and Google could develop own solutions in all concerned areas, but 
this would not give it time-based advantages over competitors. Payola is indispensable for those partners, who regard the new technology as a threat, since its diffusion could substitute their products and destroy competences. When Microsoft was co-opting partners to support Windows for enterprise computing, it had to deal with established companies, deriving large shares of revenues from the rival Unix system - and only political actions helped guarantee the needed support. Similarly, Google's attempts to gain support for Android were targeted at companies already involved in competitive ecosystems. Costly incentives for first partners motivated other companies to jump the Windows and Android bandwagons. Partner relationships, established to promote new platforms, have self-reinforcing character: large installed bases attract new partners (Hill, 1997, p. 9).

The historical analysis of Microsoft's experiences suggests that the stage of technology lifecycle is an important factor when choosing partner management techniques. It does not seem feasible to offer unequivocal guidelines for different lifecycle stages (Roberts \& Liu, 2001, 2003) - instead, managers should understand, which particular incentives and deterrents are suitable for specific stages of the lifecycle. Table 2 singles out the initial era of ferment, when companies struggle to build the largest installed base, and the period of technology platform dominance (Anderson \& Tushman, 1990). Some partner-oriented activities are effective in expanding the installed base, while not being critical for further technology development - for example, cash inducement is instrumental in co-opting complementors, but not necessary for established technological platforms.

Table 2. Changing effectiveness of partner management techniques in technology lifecycle

\begin{tabular}{|c|c|c|c|}
\hline & Partnership technique & Expanding installed base & $\begin{array}{l}\text { Managing established } \\
\text { platform }\end{array}$ \\
\hline \multirow{5}{*}{ 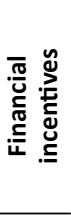 } & Minority investment & $\checkmark$ & \\
\hline & Direct transfers & $\checkmark$ & $\sqrt{ }$ \\
\hline & Third-party investment & $\checkmark$ & \\
\hline & Pricing technology & $v$ & $\sqrt{ }$ \\
\hline & Reference design & $\checkmark$ & 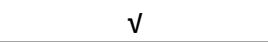 \\
\hline \multirow{4}{*}{ 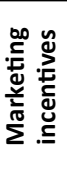 } & Promotion & $v$ & $v$ \\
\hline & Sales & 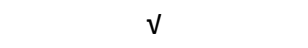 & 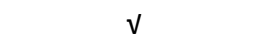 \\
\hline & Positioning own products & & $v$ \\
\hline & Certification & $\sqrt{ }$ & $\sqrt{ }$ \\
\hline \multirow{7}{*}{ 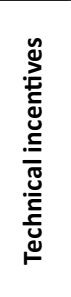 } & Platform management & $\sqrt{ }$ & $\sqrt{ }$ \\
\hline & Partner-oriented development & v & \\
\hline & Product inferiority & & $\sqrt{ }$ \\
\hline & Knowledge transfer & $v$ & $\checkmark$ \\
\hline & Learning by doing & $v$ & 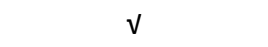 \\
\hline & Stimulating knowledge generation & $v$ & 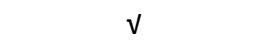 \\
\hline & Technical privileging & & v \\
\hline
\end{tabular}




\begin{tabular}{llcc}
\hline Partnership technique & Expanding installed base & $\begin{array}{c}\text { Managing established } \\
\text { platform }\end{array}$ \\
\hline Legal measures & $\mathrm{V}$ & $\mathrm{V}$ \\
$\mathrm{c}$ & & $\mathrm{V}$ \\
Partner lock-in & $\mathrm{V}$ & $\mathrm{V}$ \\
Extending platform & $\mathrm{V}$ & $\mathrm{V}$ \\
Sliminating competitors & $\mathrm{V}$ & $\mathrm{V}$ \\
\hline
\end{tabular}

Both analyzed cases prove that the competence-destroying character of innovations, which usually is a barrier to adoption and support from other companies, can be de-emphasized thanks to the use of adequate techniques. Moreover, both Microsoft and Google used recurring ties to accelerate the introduction and adoption of innovations - with partner-oriented technology development, they started competence planning for their own partners, designing products to re-use their existing skills. The repetitive ties with dedicated partners turn out to be cheaper than building new partner coalitions and co-opting necessary players for every new technology.

Literature recommends structuring technology deals in ways maximizing revenue streams throughout the entire lifecycle (Shapiro \& Varian, 1999, p. 143-148), initially encouraging adoption by means of low pricing, while in further stages benefiting from lock-in effects, and finally, carefully planning substitutive offerings. It seems too premature to address this issue based on Google's ecosystem due to the newness of developments. However, Microsoft adopted this approach to partners, not thinking about alliances as 'one-off' means to boost product diffusion, but cultivating them to achieve synergies across many businesses, and preparing for the introduction of new product generations. Technologically locked-in partners were not victims, but important social capital, useful in other projects.

\section{References}

Anderson, P., Tushman, M.L. (1990). Technological Discontinuities and Dominant Designs: A Cyclical Model of Technological Change. Administrative Science Quarterly, 35, 604633.

Astley, W.G., Zajac, E.J. (1991). Intraorganizational Power and Organizational Design: Reconciling Rational and Coalitional Models of Organization. Organization Science, 2 (4), 399-411.

Avakian, P.N. (1999). Political Realities in Strategy. Strategy \& Leadership, 27 (6), 42-48.

Baker, W.E. 1(990). Market Networks and Corporate Behavior. American Journal of Sociology, 96 (3), 589-625.

Becker, D. (2002). Microsoft Makes Rare Buyout Official, CNET News.com, September

24. Retrieved from http://news.cnet.com/2100-1040-959248.html, access date: 5 November 2012.

Borland, J. (2004). 'Plays for sure' Means Microsoft's Inside, CNET News.com, August 25. Retrieved from http://news.cnet.com/Plays-for-sure-means-Microsoftsinside/2100-1025_3-5324402.html, access date: 5 November 2012. 
Busse, T. (1998). Microsoft, Partners Cook up New Multimedia Format, Computerworld, April 6.

Cafasso, R. (1994). SAP, Microsoft Extend Relationship, Computerworld, August 29.

Caldera (1996). Complaint in the United States District Court, District of Utah, Central Division. Caldera, Inc, Plaintiff, vs. Microsoft Corporation, Defendant. Retrieved from www.digitalresearch.biz/DR/Info/COMPLAIN.HTM, access date: 5 November 2012.

Carlson, N. (2010). Google Invested in Zynga to Weaken Facebook, Business Insider, July

12. Retrieved from http://www.businessinsider.com/google-invested-in-zynga-toweaken-facebook-2010-7, access date: 5 November 2012.

Cheng, R. (2011a). Google to Buy Motorola Mobility for \$12.5B, CNET News.com, August 15. Retrieved from http://news.cnet.com/8301-1035_3-20092362-94/google-tobuy-motorola-mobility-for-\$12.5b, access date: 5 November 2012.

Cheng, R. (2011b). HTC Sues Apple Using Google Patents, Report Says, CNET News.com, September 7. Retrieved from http://news.cnet.com/8301-1035_3-20102903-94/htcsues-apple-using-google-patents-report-says, access date: 5 November 2012.

Cheng, R., Sandoval, G. (2012). How Google's Stealth Support is Buoying Samsung in Apple Fight, CNET News.com, August 10. Retrieved from http://news.cnet.com/830113579_3-57490398-37/how-googles-stealth-support-is-buoying-samsung-in-applefight, access date: 5 November 2012.

Christensen, C. (2000). The Innovator's Dilemma. New York: HarperBusiness.

Coase, R.H. (1979). Payola in Radio and Television Broadcasting. Journal of Law and Economics, 22 (2), 269-328.

Cole-Gomolski, B. (1999). EDS, Microsoft Form Alliance. Computerworld, July 21.

Cowley, S. (2002). Microsoft to Use Crystal Enterprise in CRM. Computerworld, June 19.

Cusumano, M.A., Gawer, A. (2002). The Elements of Platform Leadership. MIT Sloan Review, 43 (3), 51-58.

Das, T.K., Teng, B.S. (2002). The Dynamics of Alliance Conditions in the Alliance Development Process. Journal of Management Studies, 39 (5), 725-746.

Dash, J. (2000). Microsoft, Andersen Form Win 2K E-commerce Venture. Computerworld, March 13.

Deckmyn, D. (1999). Microsoft Signs up Infolmage for Digital Dashboard. Computerworld, October 14.

Deckmyn, D. (2000). Microsoft, Interliant Tune Exchange for ASP Market. Computerworld, March 15.

DiDio, L. (1997). Cisco, Microsoft to Lift Active Directory. Computerworld, May 12.

Dyer, J.H., Kale, P., Singh, H. (2004). When to Ally \& When to Acquire. Harvard Business Review, 81 (7-8), 109-115.

Elg, U., Johansson, U. (1997). Decision Making in Inter-firm Networks as a Political Process. Organization Studies, 18 (3), 361-384.

Evers, J., McMillan, R. (2003). Real Sues Microsoft, Alleges Monopoly Abuse. Computerworld, December 19. 
Evers, J., Roberts, P. (2003). Microsoft to Kill Popular Linux Antivirus Product. Computerworld, June 12.

Farrell, J., Saloner, G. (1986). Installed Base and Compatibility: Innovation, Product Preannouncement, and Predation. The American Economic Review, 76 (5), 940-955.

Farrell, J., Shapiro, C. (1988). Dynamic Competition with Switching Costs. RAND Journal of Economics, 19 (1), 123-137.

Garretson, C. (2002). AOL, Palm Execs See Threat from Microsoft. Computerworld, April 4. Goldberg, M., Bozman, J.S. (1995). Microsoft/DEC Deal to Buoy NT, Alpha. Computerworld, August 7.

Golde, E. (1997). Microsoft Taps CA's InocuLAN for NT Virus Protection. Computerworld, August 13.

Goodin, D. (1998a). MS Changes European ISP Deals, CNET News.com, January 20. Retrieved from http://news.cnet.com/MS-changes-European-ISPdeals/2100-1001_3-207285.html, access date: 5 November 2012.

Goodin, D. (1998b). Microsoft Changes Content Deals, CNET News.com, April 9. Retrieved from http://news.cnet.com/Microsoft-changes-content-deals/2100-1001_3-210054. html, access date: 5 November 2012.

Gulati, R. (1995). Social Structure and Alliance Formation Pattern: A Longitudinal Analysis. Administrative Science Quarterly, 40, 619-652.

Gulati, R., Higgins, M.C. (2003). Which Ties Matter When? The Contingent Effects of Interorganizational Partnerships on IPO Success. Strategic Management Journal, 24, 127-144.

Hansen, E., Festa, P. (2004). Microsoft Behind $\$ 12$ million Payment to Opera, CNET News. com, May 24. Retrieved from http://news.cnet.com/2100-1032_3-5218163.html, access date: 5 November 2012.

Heskett, B. (1998). CA's NT Claims under Fire, CNET News.com, April 29. Retrieved from http://news.cnet.com/CAs-NT-claims-under-fire/2100-1001_3-210721.html, access date: 5 November 2012.

Hill, Ch.W.L. (1997). Establishing a Standard: Competitive Strategy and Technological Standards in Winner-take-all Industries. Academy of Management Executive, 11 (2), 7-25. lansiti, M., Levien, R. (2004). Strategy as Ecology. Harvard Business Review, 82 (3), 69-78. IDC 2007. The Economic Impact of IT, Software, and the Microsoft Ecosystem on the Global Economy, IDC White Paper, October 2007. Retrieved from http://download. microsoft.com/download/9/a/2/9a22a977-f5ce-40b0-b9cf-79f49e7e5ff5/IDC_ Global_White_Paper.doc, access date: 5 November 2012.

Johnston, M. (1998). RealNetworks Senate Demo Slams Microsoft. Computerworld, July 23. Johnston, S.J. (1994). Microsoft Settles for Piece of the Stac. Computerworld, June 27. Johnston, S.J. (1995). Antivirus Utilities Hold Strong. Computerworld, May 29.

Johnston, S.J., Scannell, E., Ballou, M.C. (1994). Chicago Beta Contract Angers Top Developers. Computerworld, April 25.

Kale, P., Puranam, P. (2004). Choosing Equity Stakes in Technology-Sourcing Relationships: An Integrative Framework. California Management Review, 46 (3), 77-99. 
Klincewicz, K. (2005). Strategic alliances in the high-tech industry, Berlin: Logos Verlag. Retrieved from http://otworzksiazke.pl/images/ksiazki/strategic_alliances_in_the_ high-tech_industry/strategic_alliances_in_the_high-tech_industry.pdf, access date: 5 November 2012. Krigel, B.L. (1999). Why Did Microsoft Keep Browser Feature from Partners? CNET News.com, July 30. Retrieved fromhttp://news.cnet.com/Why-didMicrosoft-keep-browser-feature-from-partners/2100-1023_3 229276.html, access date: 5 November 2012.

Luening, E. (1998). Short Take: Symantec, MS Team on Faxing, CNET News.com, January 20. Retrieved from http://news.cnet.com/Short-Take-Symantec,-MS-team-onfaxing/2110-1001_3-207259.html, access date: 5 November 2012.

Luening, E. (2001). Microsoft Enlists VC Firm in .Net Push, CNET News.com, August 14. Retrieved from http://news.cnet.com/2100-1001-271568.html, access date: 5 November 2012.

MacDonald, Ch. (1997). MS Woos Banks with Fee Cuts, CNET News.com, March 27. Retrieved from http://news.cnet.com/MS-woos-banks-with-feecuts/2100-1017_3-278327.html, access date: 5 November 2012.

McLoughlin, I., Koch, Ch., Dickson, K. (2001). What's This "Tosh"?: Innovation Networks and New Product Development as a Political Process. International Journal of Innovation Management, 5 (3), 275-298.

McMillan, R. (2004). Sun-Microsoft Deal Raises OpenOffice Questions. Computerworld, September 16.

McMillan, R., Evers, J. (2004). Microsoft behind \$50M SCO Investment. Computerworld, March 11.

Mohan, S. (1995). Microsoft Accused of MAPI Secrets. Computerworld, June 5.

Mohan, S. (1997). HP/MS Deal a Boon to Messaging, CNET News.com, March 26. Retrieved from http://news.cnet.com/HPMS-deal-a-boon-tomessaging/2100-1001_3-278318.html, access date: 5 November 2012.

Nash, K.S. (1998). Microsoft to Sell its $10 \%$ Stake in RealNetworks. Computerworld, November 23.

Niccolai, J., Trott, B. (1997). DOJ Documents: Microsoft Leaned on Compaq. Computerworld, October 23.

Ouellette, T. (1995). Microsoft Pulls Oars out of Workflow Waters. Computerworld, September 4.

Ouellette, T., Weinberg, N. (1995). Win 95 Polishes Wang Image. Computerworld, April 17. Padgett, J.F., Ansell, Ch.K. (1993). Robust Action and the Rise of the Medici, 1400-1434. American Journal of Sociology, 98 (6), 1259-1319.

Pelline, J. (1996). Microsoft Ropes in Another ISP, CNET News.com, July 30. Retrieved from http://news.cnet.com/Microsoft-ropes-in-another-ISP/2100-1023_3-219402. html, access date: 5 November 2012.

Ricciuti, M. (1996). Microsoft Juices up Shockwave, CNET News.com, June 3. Retrieved from http://news.cnet.com/Microsoft-juices-up-Shockwave/2100-1023_3-213525. html, access date: 5 November 2012. 
Ring, P.S., Van de Ven, A.H. (1994). Developmental Processes of Cooperative Interorganizational Relationships. Academy of Management Review, 19 (1), 90-118.

Roberts, E.B., Liu, W.K. (2001). Ally or Acquire? How Technology Leaders Decide. MIT Sloan Management Review, 43 (1), 26-34.

Roberts, E.B., Liu, W.K. (2003). Ally or Acquire? Case Studies of Compaq and Cisco as Additional Tests of the External Technology Life Cycle Model. MIT Sloan School of Management Working Paper, 4421-03.

Roberts, P. (2004). Microsoft, InterTrust Settle Patent Case for $\$ 440 M$. Computerworld, April 12.

Rokkan, A.I., Heide, J.B., Wathne, K.H. (2003). Specific Investments in Marketing Relationships: Expropriation and Bonding Effects. Journal of Marketing Research, 40, 210-224.

Shankland, S. (1999). Microsoft Funds Perl Open-source Effort, CNET News.com, June 2. Retrieved from http://news.cnet.com/Microsoft-funds-Perl-open-sourceeffort/2100-1001_3-226633.html, access date: 5 November 2012.

Shapiro, C., Varian, H.R. (1999). Information Rules. A Strategic Guide to the Network Economy. Boston: Harvard Business School Press.

Sliwa, C. (1999). Upstart Java Clone Backed By Microsoft. Computerworld, June 21.

Sliwa, C. (2000). New Microsoft Technology Helps Suppliers "Accelerate" Business on the Web. Computerworld, November 8.

Sykes, R. (1998). In Another Courtroom, Microsoft Under Fire. Computerworld, October 15. Thibodeau, P. (1999). MS/DOJ: Did Compaq Change Handheld Partners to Please Microsoft? Computerworld, February 18.

Uzzi, B. (1999). Embeddedness in the Making of Financial Capital: How Social Relations and Networks Benefit Firms Seeking Financing. American Sociological Review, 64: 481-505.

Vijayan, J. (2001). Microsoft Revises Software Licensing Program for ASPs. Computerworld, December 3.

Wasserman, E. (1999). IBM Exec Details Microsoft Tactics. Computerworld, June 7.

Wathne, K.H., Heide, J.B. (2000). Opportunism in Interfirm Relationships: Forms, Outcomes, and Solutions. Journal of Marketing, 64, 36-51.

Weinstein, N. (2001). Thirty-eight Xbox Games Available, CNET News.com, December 28. Retrieved from http://news.cnet.com/2110-1040-277469.html, access date: 5 November 2012.

Wilcox, J. (2001a). Microsoft to Charge for MP3 Ripping, CNET News.com, July 16. Retrieved from http://news.cnet.com/2100-1001-269967.html, access date: 5 November 2012.

Wilcox, J. (2001b). Microsoft, Kodak Settle XP Dispute, CNET News.com, August 12. Retrieved from http://news.cnet.com/Microsoft,-Kodak-settle-XPdispute/2100-1003_3-271490.html, access date: 5 November 2012.

Wong, W. (1997). MCl Custom Builds 'net Pipeline for Microsoft. Computerworld, October 21. 


\begin{abstract}
Polish)
Artykuł prezentuje alianse technologiczne jako działania o charakterze politycznym, pomagajqce budować koalicje, kooptować sojuszników i eliminować rywali. W oparciu o przykłady ekosystemów partnerskich firm Microsoft i Google, omówione zostajq specyficzne techniki stosowane w odniesieniu do partnerów i ich przydatność dla firm technologicznych. Artykuł oferuje bogaty przeglą faktograficzny, dotyczq̨cy rozwoju platform Microsoft Windows i Google Android, w połqczeniu z działaniami, podejmowanymi przez obie firmy w celu zapewnienia wsparcia ze strony firm partnerskich. Skuteczność zachęt o charakterze finansowym, marketingowym i technologicznym, jak również działań odstraszajqcych, jest uzależniona od oczekiwanych rezultatów (taki jak: redukcja kosztów transakcyjnych, uzależnianie partnera, stymulowanie innowacyjności lub ograniczanie rozwoju konkurencyjnych produktów), jak również etapu cyklu życia technologii. Artykuł pomaga kształtować strategie współpracy z partnerami i optymalizować inwestycje, niezbędne dla motywowania i kontrolowania partnerów.

Słowa kluczowe: sojusze technologiczne, zarzqdzanie partnerami, perspektywa polityczna, Microsoft, Google
\end{abstract}

